\title{
Ruminal fermentation, milk fatty acid profiles, and productive performance of Holstein dairy cows fed 2 different safflower seeds ${ }^{1}$
}

\author{
C. M. Dschaak, ${ }^{\star}$ C. T. Noviandi, ${ }^{\star}$ J.-S. Eun, ${ }^{\star 2}$ V. Fellner,† A. J. Young, ${ }^{\star}$ D. R. ZoBell, ${ }^{\star}$ and C. E. Israelsen‡ \\ *Department of Animal, Dairy, and Veterinary Sciences, Utah State University, Logan 84322-4815 \\ †Department of Animal Science, North Carolina State University, Raleigh 27695-7621 \\ ¥Cooperative Extension, Utah State University, Logan 84322-4900
}

\section{ABSTRACT}

A lactation trial was conducted to determine the effects of supplementing whole safflower seeds (SS) on ruminal fermentation, lactational performance, and milk fatty acid (FA) profiles. Nine multiparous Holstein cows (days in milk $=110 \pm 20$ ) were used in a replicated $3 \times 3$ Latin square design. Each period lasted $21 \mathrm{~d}$, with $14 \mathrm{~d}$ of adaptation and $7 \mathrm{~d}$ of data collection. Within square, cows were randomly assigned to a sequence of 3 dietary treatments as follows: cottonseed total mixed ration (TMR; CST), conventional SS (variety S-208) TMR (CSST), and NutraSaff SS (Safflower Technologies International, Sidney, MT) TMR (NSST). Diets contained approximately $63 \%$ forage ( $36 \%$ alfalfa hay, $4 \%$ grass hay, and $23 \%$ corn silage) and $37 \%$ concentrate supplemented with $2 \%$ cottonseed to the CST and 3\% conventional or NutraSaff SS to the CSST or the NSST, respectively. Intake of dry matter (DM) averaged $21.8 \mathrm{~kg} / \mathrm{d}$ and did not differ across diets, but feeding the NSST decreased intake of neutral detergent fiber (NDF) due to lower dietary concentration of NDF in the NSST. Digestibilities of DM and nutrients were similar among treatments. No differences in yields of milk or milk components were observed in response to supplementing SS. Dietary treatments did not affect ruminal $\mathrm{pH}$, total or molar proportions of ruminal volatile FA, and ammonia-N. However, cows fed SS had a higher molar proportion of isobutyrate than those fed the CST diet. Ruminal C16:0 FA concentration increased with the CST, whereas C18:1 cis-9 and C18:2 n-6 tended to increase with SS supplementation, indicating that conventional and NutraSaff SS were partially protected from microbial biohydrogenation. Supplementing SS decreased milk C16:0 concentration, whereas it increased C18:1 cis-9 and C18:1 trans-9. Milk FA C18:1 trans-11 and cis-9,

\footnotetext{
Received May 17, 2011.

Accepted June 16, 2011.

${ }^{1}$ Approved as Journal Paper Number 8310 of the Utah Agricultural Experiment Station, Utah State University, Logan.

${ }^{2}$ Corresponding author: jseun@usu.edu
}

trans-11 conjugated linoleic acid increased and tended to increase with feeding the NSST, respectively, but not the CSST diet. In conclusion, supplementing diets with whole SS at $3 \%$ of dietary DM can be an effective strategy of fat supplementation to lactating dairy cows without negative effects on lactational performance and milk FA profiles.

Key words: safflower seed, ruminal fermentation, milk fatty acid, lactational performance

\section{INTRODUCTION}

Addition of fats in lactating dairy cow diets allows for the maintenance of energy density while increasing fiber intake, resulting in stabilization of ruminal fermentation (Allen, 1997). In addition, a fat supplement that maximizes DMI and ruminal fiber digestion increases milk production and milk component yield, and improves health and reproduction of dairy cows (Overton and Waldron, 2004). The need for various fat sources that are digestible in the small intestine, easy to use, and cost-effective has drawn a lot of attention with the increasing costs of ration ingredients. In the western and central United States, safflower (Carthamus tinctorius L., Asteraceae) has been widely grown because of tolerance to hot and dry climates ( $\mathrm{Li}$ and Mündel, 1996; Bradley et al., 1999). Safflower seed (SS) is usually $106 \%$ higher in fat and $21 \%$ lower in CP than is whole linted cottonseed (CS; Dschaak et al., 2010). The high oil concentration of SS makes it an attractive energy-dense feed for animals with high energy requirements, such as lactating dairy cattle. Alizadeh et al. (2010) reported that SS can be included up to $5 \%$ of dietary DM alongside CS for early lactating cows without affecting feed intake while maintaining normal ruminal fermentation, peripheral energy supply, and milk production. We recently conducted a lactation study to assess productive performance of dairy cows fed varying levels of whole NutraSaff SS (NSS), a new variety of SS (Safflower Technologies International, Sidney, MT) containing higher oil and lower fiber concentrations than traditional SS varieties (Bergman et al., 2007). The study demonstrated that NSS can replace CS and 
be fed to lactating dairy cows without negative effects on lactational performance up to 3\% DM (Dschaak et al., 2010). Feeding the NSS improved efficiency of use of feed $\mathrm{N}$ to milk $\mathrm{N}$ and decreased MUN; however, how feeding the SS affects ruminal fermentation and FA profiles has not been assessed.

In addition to the benefits on nutrient utilization, feeding NSS enhanced functional quality of milk with increased cis-9, trans-11 conjugated linoleic acid (CLA) concentration, which is an additional benefit to human health (Dschaak et al., 2010). However, the beneficial effect of NSS was counterbalanced by an unfavorable increase of trans-10 18:1 fatty acid (FA). Many dietary treatments producing high levels of CLA also induce a shift in the major biohydrogenation $(\mathbf{B H})$ pathways characterized by increased accumulation of trans-10 and trans-11 18:1 FA. The increase in the trans-10 18:1 content of milk fat is indicative of complex changes in ruminal BH pathways (Lock et al., 2007). Therefore, further research is needed to identify if other CLA isomers or 18:1 trans FA would be involved to affect milk fat yield when SS are fed in lactating dairy cow diets.

We hypothesized that supplementation of SS in the lactating dairy cow diet would improve nutrient utilization and milk FA profiles, but a conventional SS (CSS) and NSS elicit different milk FA profiles due to their unique FA compositions. Our objective was to assess lactational performance, ruminal fermentation, and milk FA profiles and their effects on milk fat yield when dairy cows were fed CSS or NSS.

\section{MATERIALS AND METHODS}

The dairy cows used in this study were cared for according to the Live Animal Use in Research Guidelines of the Institutional Animal Care and Use Committee at Utah State University (Logan).

\section{Cows, Experimental Design, and Diets}

Nine multiparous lactating Holstein cows were used; 3 cows were surgically fitted with ruminal cannula, and they consisted of 1 of 3 squares. Days in milk ranged from 70 to 108 and from 100 to 144 for noncannulated and cannulated cows, respectively, at the start of the experiment. Average BW was $656 \pm 130.9 \mathrm{~kg}$ at the beginning of the experiment and $705 \pm 123.3 \mathrm{~kg}$ at the end of the experiment.

The design of the experiment was a replicated $3 \times$ 3 Latin square, with each period lasting $21 \mathrm{~d}$ (14 d of treatment adaptation and $7 \mathrm{~d}$ of sampling and data collection). The 3 squares were conducted simultaneously. Within square, cows were randomly assigned to a sequence of 3 dietary treatments consisting of CS
TMR without whole SS (CST), CSS TMR (CSST), and NSS TMR (NSST; Table 1). The CSS (variety S-208) is a normal white hull seed cultivar and a linoleic oil variety, containing $37.6 \%$ ether extract and $42.2 \%$ NDF, whereas the NSS contains higher oil (45.8\% ether extract) and lower fiber concentration (23.7\% NDF) than CSS (Table 2). The diets had approximately $63.0 \%$ forage and $37.0 \%$ concentrate. The CSS and NSS added to the CSST and NSST diets replaced whole linted CS in the CST diet, and Table 1 shows the diet composition. In our previous study (Dschaak et al., 2010), efficiency of use of feed $\mathrm{N}$ to milk $\mathrm{N}$ increased by feeding NSS, and we speculated that N solubility of NSS may be lower than that of CS, thereby influencing ruminal ammonia production and, consequently, MUN concentration. Although $\mathrm{N}$ utilization was not our primary interest in the current study, we would assess $\mathrm{N}$ fermentation in the rumen when SS was supplemented. In addition, Dschaak et al. (2010) reported that milk fat concentration was greatly affected when NSS was included at $4 \% \mathrm{DM}$ with a $15 \%$ reduction, and at the inclusion rate increase of 18:1 trans-10 milk FA, was much more pronounced compared with lower inclusion rates of NSS. These findings indicate that inclusion of SS more than 3\% DM may induce complex changes in ruminal $\mathrm{BH}$ pathways and cause diet-induced milk fat depression. Consequently, the CSS and the NSS were added at 3.0 and $3.1 \%$ DM, respectively, to formulate isonitrogenous diets and avoid possible negative effects of feeding SS on milk fat yield. Diets were formulated based on NRC (2001) recommendations to provide sufficient $\mathrm{NE}_{\mathrm{L}}$, metabolizable protein, vitamins, and minerals to produce $35 \mathrm{~kg}$ of milk/d with $3.5 \%$ fat and $3.0 \%$ true protein.

Cows were housed in individual tie-stalls fitted with rubber mattresses, bedded with straw, and were fed a TMR for ad libitum intake with at least $10 \%$ of daily feed refusal. All cows were individually fed twice daily at 0830 and $1500 \mathrm{~h}$ with approximately 70 and $30 \%$ of total daily feed allocation at each feeding, respectively. Feed offered and refused was recorded daily, and daily samples were collected to determine DMI. Cows had free access to water.

Cows were milked twice daily at 0400 and $1600 \mathrm{~h}$. Milk production was recorded daily throughout the experiment. Cows were turned outside to a dry lot for exercise for at least $1 \mathrm{~h}$ daily in the morning after being milked. Milk was sampled during the a.m. and p.m. milkings on 2 consecutive days (d 16 and 17) in each period. Individual milk samples were analyzed for fat, true protein, lactose, and MUN by the Rocky Mountain DHIA Laboratory (Logan, UT). Milk composition was expressed on weighted milk yield of a.m. and p.m. samples. Yields of milk fat, true protein, and lactose were 
Table 1. Ingredients of the TMR fed to lactating cows

\begin{tabular}{lccc}
\hline & & Diet $^{1}$ & \\
\cline { 2 - 4 } Ingredient, \% of DM & CST & CSST & NSST \\
\hline Alfalfa hay & 35.9 & 35.8 & 35.8 \\
Grass hay & 4.28 & 4.27 & 4.24 \\
Corn silage & 23.0 & 22.9 & 22.9 \\
Cottonseed, whole & 2.35 & 3.01 & - \\
CSS, ${ }^{2}$ whole & - & - & 3.10 \\
NSS, whole & - & 18.4 & 18.4 \\
Corn, steam flaked & 18.6 & 6.5 & 6.4 \\
Beet pulp, pellets & 6.5 & 5.10 & 5.10 \\
Corn hominy & 5.20 & 1.30 & 1.30 \\
Corn DDGS & 1.40 & 0.72 & 0.73 \\
Soybean meal & 0.73 & 0.31 & 0.31 \\
Blood meal, flash dried & 0.32 & 0.20 & 0.21 \\
Urea & 0.21 & 0.18 & 0.22 \\
Salt & 0.22 & 1.10 & 0.19 \\
Sodium bicarbonate & 0.19 & 1.10 & 1.10 \\
Mineral and vitamin mix $^{5}$ & & & \\
\hline
\end{tabular}

${ }^{1} \mathrm{CST}=$ whole linted cottonseed TMR without whole safflower seed; CSST $=$ whole conventional safflower seed TMR; NSST = whole NutraSaff safflower seed (Safflower Technologies International, Sidney, MT) TMR.

${ }^{2} \mathrm{CSS}=$ conventional safflower seed (variety S-208).

${ }^{3} \mathrm{NSS}=$ NutraSaff safflower seed.

${ }^{4}$ Dried distillers grains with solubles.

${ }^{5}$ Formulated to contain (per $\mathrm{kg}$ of $\mathrm{DM}$ ): $71.3 \mathrm{~g}$ of $\mathrm{P}$ (from monosodium phosphate), $68.9 \mathrm{~g}$ of $\mathrm{K}$ (from potassium sulfate), $94.6 \mathrm{mg}$ of Se (from sodium selenate), $6.56 \mathrm{~g}$ of $\mathrm{Cu}$ (from copper sulfate), $25.8 \mathrm{~g}$ of $\mathrm{Zn}$ (from zinc sulfate), 4,131.3 kIU of vitamin A, 515.4 kIU of vitamin D, 5,728.8 IU of vitamin E, and $19.6 \mathrm{mg}$ of Rumensin (Elanco Animal Health, Greenfield, IN).

Table 2. Chemical composition of oilseeds and the diets (\% DM)

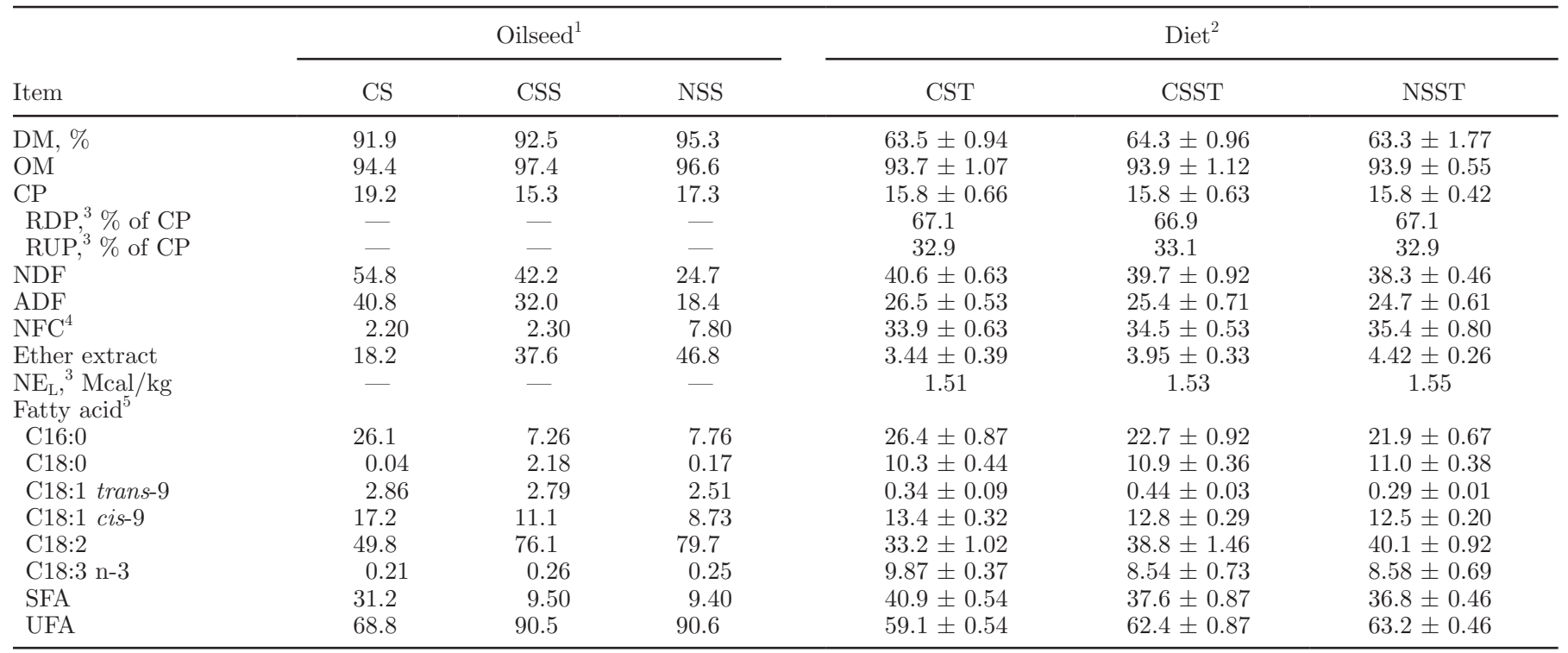

${ }^{1}$ Analysis performed on 1 composite sample for the study. CS = cottonseed, whole; CSS = conventional safflower seed (variety S-208); NSS = NutraSaff safflower seed (Safflower Technologies International, Sidney, MT).

${ }^{2}$ Analysis performed on 3 period samples; CST $=$ whole linted cottonseed TMR without whole safflower seed; CSST = whole conventional safflower seed TMR; NSST = whole NutraSaff safflower seed TMR.

${ }^{3}$ Based on tabular value (NRC, 2001).

${ }^{4} \mathrm{NFC}=100-\mathrm{CP}-\mathrm{NDF}-$ ether extract - ash.

${ }^{5}$ Fatty acid composition was expressed as $\mathrm{g} / 100 \mathrm{~g}$ of fatty acid methyl esters. SFA = saturated fatty acids; UFA = unsaturated fatty acids. 
calculated by multiplying milk yield from the respective day by fat, true protein, and lactose concentrations of the milk from an individual cow.

\section{Sampling, Data Collection, and Chemical Analyses}

Corn silage, chopped alfalfa hay, grass hay, and concentrates were sampled weekly to determine DM concentration. Diets were adjusted weekly to account for changes in DM concentration. Diets of TMR samples were collected on d 20 and 21 for particle size analysis by using the Penn State Particle Separator as described by Kononoff et al. (2003), equipped with 3 sieves (19, 8 , and $1.18 \mathrm{~mm}$ ) and a pan. The recommended proportions for TMR are 2 to $8 \%$ on the $19-\mathrm{mm}$ sieve, 30 to $50 \%$ on the $8-\mathrm{mm}$ sieve, and 30 to $50 \%$ on the $1.18-\mathrm{mm}$ sieve (Kononoff and Heinrichs, 2007), and all diets were within the recommended ranges.

Samples of the TMR fed and orts for individual cows were collected daily during the data collection period, dried at $60^{\circ} \mathrm{C}$ for $48 \mathrm{~h}$, ground to pass a $1-\mathrm{mm}$ screen (standard model 4; Arthur H. Thomas Co., Philadelphia, PA), and stored for subsequent analyses. Contents of DM of the samples were used to calculate intakes and digestibilities of DM and nutrients.

Analytical DM concentration of samples was determined by oven drying at $135^{\circ} \mathrm{C}$ for $3 \mathrm{~h}$; OM was determined by ashing, and $\mathrm{N}$ content was determined using an elemental analyzer (LECO TruSpec N; Leco Corp., St. Joseph, MI; AOAC, 2000). The NDF and ADF concentrations were sequentially determined using an $\mathrm{ANKOM}^{200 / 220}$ Fiber Analyzer (Ankom Technology Corp., Macedon, NY) according to the methodology supplied by the company, which is based on the methods described by Van Soest et al. (1991). Sodium sulfite was used in the procedure for NDF determination and pretreatment with heat-stable amylase (Type XI-A from Bacillus subtilis; Sigma-Aldrich Corp., St. Louis, MO).

Weekly samples of dietary ingredients were analyzed for total FA concentration and FA profile according to the procedure of Sukhija and Palmquist (1988) and Kleinschmit et al. (2007) using a GLC (model 6890 series II; Hewlett Packard Co., Avondale, PA) fitted with a flame ionization detector. The injector port temperature was $230^{\circ} \mathrm{C}$ with a split ratio of $20: 1$. The column was $100 \mathrm{~m}$, with an inside diameter of 0.25mm (CP-Sil 88; Varian Inc., Lake Forest, CA). The carrier gas was helium at a rate of $2.0 \mathrm{~mL} / \mathrm{min}$. The initial oven temperature was $50^{\circ} \mathrm{C}$, held for $1 \mathrm{~min}$, and then increased to $145^{\circ} \mathrm{C}$ at a rate of $5^{\circ} \mathrm{C}$ per min and held for $30 \mathrm{~min}$. The temperature was then increased at $10^{\circ} \mathrm{C} / \mathrm{min}$ to $190^{\circ} \mathrm{C}$ and held for $30 \mathrm{~min}$. Finally, the temperature was raised at $5^{\circ} \mathrm{C} / \mathrm{min}$ to $210^{\circ} \mathrm{C}$ and held for $35 \mathrm{~min}$. The total run per sample lasted $123.5 \mathrm{~min}$.

Weighted composite milk samples from individual cows were analyzed for FA composition. Milk fat was extracted by boiling milk in a detergent solution (Hurley et al., 1987). Extracted fat was derivatized to methyl esters using an alkaline methylation procedure by mixing $40 \mathrm{mg}$ of fat with a sodium methoxide methylation reagent $\left(\mathrm{NaOCH}_{3} / \mathrm{MeOH}\right)$ as described by Chouinard et al. (1999). After FA methyl esters were formed, anhydrous calcium chloride pellets were added and allowed to stand for $1 \mathrm{~h}$ to remove water in the sample. Samples were then centrifuged at $1,016 \times g$ at $4^{\circ} \mathrm{C}$ for 20 min.

Separation of FA was achieved by using a GLC (model 6890 series II; Hewlett Packard Co.) fitted with a flame ionization detector. Samples containing methyl esters in hexane $(1 \mu \mathrm{L})$ were injected through the split injection port $(100: 1)$ onto the column (CPSil 88). The oven temperature was set at $80^{\circ} \mathrm{C}$ and held for $10 \mathrm{~min}$, then increased to $190^{\circ} \mathrm{C}$ at $12^{\circ} \mathrm{C} / \mathrm{min}$ for $39 \mathrm{~min}$. The temperature was then increased again to $218^{\circ} \mathrm{C}$ at $20^{\circ} \mathrm{C} / \mathrm{min}$ and held for $21 \mathrm{~min}$. The injector and detector were set at $250^{\circ} \mathrm{C}$. The total run time was $71 \mathrm{~min}$. Heptadecanoic acid was used as a qualitative internal standard. Individual FA concentrations were obtained by taking the specific FA area as a percentage of total FA, and were reported as $\mathrm{g} / 100 \mathrm{~g}$ of FA methyl esters.

Feed DM and nutrient digestibility was measured during the last week in each period using acid-insoluble ash (AIA) as an internal marker (Van Keulen and Young, 1977). Fecal samples (approximately $200 \mathrm{~g}$ of wet weight) were collected for each cow from the rectum twice daily (a.m. and p.m.) every $12 \mathrm{~h}$, moving ahead $2 \mathrm{~h}$ each day for the $6 \mathrm{~d}$ of fecal sampling beginning on d 15. This schedule provided 12 representative samples of feces for each cow. Samples were immediately subsampled (about $50 \mathrm{~g}$ ), composited across sampling times for each cow and each period, dried at $55^{\circ} \mathrm{C}$ for $72 \mathrm{~h}$, ground to pass a 1-mm screen (standard model 4), and stored for chemical analysis. Apparent total tract nutrient digestibilities were calculated from concentrations of AIA and nutrients in diets fed, orts, and feces using the following equation: apparent digestibility = $100-\left[100 \times\left(\mathrm{AIA}_{\mathrm{d}} / \mathrm{AIA}_{\mathrm{f}}\right) \times\left(\mathrm{N}_{\mathrm{f}} / \mathrm{N}_{\mathrm{d}}\right)\right]$, where $\mathrm{AIA}_{\mathrm{d}}=$ AIA concentration in the diet actually consumed, AIA $_{f}$ $=$ AIA concentration in the feces, $\mathrm{N}_{\mathrm{f}}=$ concentration of the nutrient in the feces, and $\mathrm{N}_{\mathrm{d}}=$ concentration of the nutrient in the diet actually consumed (Eun and Beauchemin, 2005). 


\section{Ruminal Fermentation Characteristics}

Ruminal $\mathrm{pH}$ was continuously measured for 2 consecutive days starting on d 18 using the Lethbridge Research Centre Ruminal pH Measurement System (LRCpH; Dascor Inc., Escondido, CA) as described by Penner et al. (2006). Readings in $\mathrm{pH}$ buffers 4 and 7 were recorded before placing the $\mathrm{LRCpH}$ system in the rumen. Ruminal $\mathrm{pH}$ readings were taken every 30 $\mathrm{s}$ and stored by the data logger. After about $48 \mathrm{~h}$ of continuous $\mathrm{pH}$ measurement, the $\mathrm{LRCpH}$ was removed from the rumen, washed in $39^{\circ} \mathrm{C}$ water, and millivolt readings were recorded in $\mathrm{pH}$ buffers 4 and 7 . The daily ruminal $\mathrm{pH}$ data was averaged for each minute and summarized as minimum $\mathrm{pH}$, mean $\mathrm{pH}$, and maximum $\mathrm{pH}$. In addition, daily episodes, duration $(\mathrm{h} / \mathrm{d})$, and area $(\mathrm{pH} \times \min )$ when ruminal $\mathrm{pH}$ was less than 5.5 were calculated. The threshold 5.5 was assigned because it has been defined by others (Beauchemin and Yang, 2005) to cause ruminal acidosis.

Ruminal contents were sampled from cannulated cows at 0,3 , and $6 \mathrm{~h}$ after the a.m. feeding on $\mathrm{d} 20$ and 21. Approximately $1 \mathrm{~L}$ of ruminal contents were obtained from the anterior dorsal, anterior ventral, medial ventral, posterior dorsal, and posterior ventral locations within the rumen, composited by cow, and strained through a polyester screen (pore size $355 \mu \mathrm{m}$; B \& SH Thompson Co. Ltd., Ville Mont-Royal, QC, Canada). Five milliliters of the filtered ruminal fluid was added to $1 \mathrm{~mL}$ of $1 \%$ sulfuric acid and samples were retained for $\mathrm{NH}_{3}-\mathrm{N}$ determination. The concentration of $\mathrm{NH}_{3}-\mathrm{N}$ in the ruminal contents was determined as described by Rhine et al. (1998). Another $5 \mathrm{~mL}$ of the filtered ruminal fluid was taken at $3 \mathrm{~h}$ after the a.m. feeding and added to $1 \mathrm{~mL}$ of $25 \%$ of meta-phosphoric acid, and the samples were retained for VFA determination. The VFA were quantified using a GLC (model 6890 series II; Hewlett Packard Co.) with a capillary column $(30 \mathrm{~m} \times 0.32 \mathrm{~mm}$ i.d., 1- $\mu \mathrm{m}$ phase thickness, Zebron ZB-FAAP; Phenomenex Inc., Torrance, CA), and flame-ionization detection. Crotonic acid was used as an internal standard. The oven temperature was $170^{\circ} \mathrm{C}$ held for $4 \mathrm{~min}$, which was then increased by $5^{\circ} \mathrm{C} /$ min to $185^{\circ} \mathrm{C}$, and then by $3^{\circ} \mathrm{C} / \min$ to $220^{\circ} \mathrm{C}$, and held at this temperature for $1 \mathrm{~min}$. The injector temperature was $225^{\circ} \mathrm{C}$, the detector temperature was $250^{\circ} \mathrm{C}$, and the carrier gas was helium. In addition, $15 \mathrm{~mL}$ of blended ruminal fluid was collected and freeze-dried for ruminal FA analysis. The samples were methylated (Kramer et al., 1997) and analyzed for long-chain FA by GLC (model CP-3380; Varian Inc., Walnut Creek, CA). Fatty acid methyl esters were separated on a $100 \mathrm{~m} \times$ $0.25 \mathrm{~mm} \times 0.2 \mu \mathrm{m}$ film thickness fused-silica capillary column (SP-2560; Supelco Inc., Bellefonte, PA). Verifi- cation of peak identity was established by comparison of peak retention times to known standards.

\section{Statistical Analyses}

Data were summarized for each cow by measurement period. All data were statistically analyzed using the mixed model procedure in SAS (SAS Institute, 2001). Data for intake, digestibility, and milk production were analyzed with a model that included the effect of dietary treatment. Cow, period, and cow by period by square were the terms of the random statement.

Data for VFA profiles and $\mathrm{NH}_{3}-\mathrm{N}$ concentration were analyzed with the same model except that the fixed effect of time after feeding was included using the repeated option. Cow and period were the terms of the random statement. The covariance structure that resulted in the lowest values for the Akaike information criteria and Schwartz's Bayesian criterion was used (Littell et al., 1998). Data for DMI and milk yield were reported using the heterogeneous compound symmetry structure, whereas efficiency of feed was analyzed by the autoregressive structure. Data for milk components, efficiency of $\mathrm{N}$ utilization, and VFA were analyzed using the unstructured covariance structure. In addition, data for $\mathrm{NH}_{3}-\mathrm{N}$ was analyzed by the unstructured and compound symmetry variance-covariance structure.

Residual errors were used to test dietary treatments. Least squares means are reported throughout, and differences were considered significant at $P<0.05$, and trends were discussed at $P<0.10$. Treatment means were compared using a protected $(P<0.05)$ LSD test.

\section{RESULTS AND DISCUSSION}

In recent years, the number of safflower varieties available has increased dramatically, and they have been popularly grown in the Intermountain West (i.e., Utah, Idaho, Wyoming, Montana, and parts of Arizona and Nevada) because of reasonable economic returns, a great option in crop rotations, and a potential as a fat supplement in dairy diets. The main findings show that SS supplementation did not affect nutrient digestibility and lactational performance, principally through minimal effects on ruminal fermentation. Collectively, this suggests that SS supplementation is effective for maintaining normal productive performance of lactating dairy cows without deleterious effects on milk and milk fat yields at a dietary inclusion rate investigated in this study.

\section{Characteristics of Experimental Diets}

The chemical composition of the experimental diets is listed in Table 2. Concentrations of $\mathrm{CP}$ as well as 
fractions of RDP and RUP were similar across dietary treatments. Replacing CS with NSS decreased NDF and ADF concentrations in the NSST due to lower NDF $(23.7 \% \mathrm{DM})$ and $\mathrm{ADF}(18.4 \% \mathrm{DM})$ concentrations of NSS compared with those of CS (58.8 and 40.8\% $\mathrm{DM}$ of NDF and ADF, respectively). As expected, CSS contained higher NDF (42.2\%) and ADF (32.0\%) concentrations compared with the NSS, resulting in a medium range of fiber concentrations among diets. Ether extract concentration increased by adding SS in diets due to higher ether extract concentration of CSS $(37.6 \%)$ and NSS (45.8\%) compared with that of CS $(17.2 \%)$, resulting in increased $\mathrm{NE}_{\mathrm{L}}$ in the diets.

Fatty acid profiles of the experimental diets are presented in Table 2. Due to higher C16:0 concentration of CS (26.1 g/100 g of FA methyl esters) compared with that of CSS and NSS (7.3 and $7.8 \mathrm{~g} / 100 \mathrm{~g}$ of FA methyl esters, respectively), the CST contained higher C16:0 than either the NSST or the CSST. Dschaak et al. (2010) reported when substituting CS with NSS, C16:0 decreased in diets regardless of NSS level. The addition of SS increased the C18:2 concentration due to higher C18:2 concentration in CSS and NSS (76.1 and 79.7 and $\mathrm{g} / 100 \mathrm{~g}$ of FA methyl esters, respectively) compared with that of CS $(49.8 \mathrm{~g} / 100 \mathrm{~g}$ of FA methyl esters). An increased concentration of C18:2 was also reported by Dschaak et al. (2010) when CS was substituted with NSS. In addition, Beauchemin et al. (2009) observed an increased C18:2 concentration in the lactation diet when feeding crushed sunflower seed at $10.6 \%$ DM. Sunflower seed is another dietary oilseed that is comparable to SS due to relatively high C18:2 concentration, but the sunflower seed contains lower C18:2 than NSS (70.1 vs. $79.7 \mathrm{~g} / 100 \mathrm{~g}$ of FA methyl esters). Adding CSS or NSS in diets decreased saturated FA, but increased unsaturated FA compared with the CST.
The composition of FA was similar between the CSST and the NSST.

\section{Intake and Digestibility}

Intake of DM averaged $21.8 \mathrm{~kg} / \mathrm{d}$ across all treatments and was not affected by the addition of SS in the diets (Table 3). Alizadeh et al. (2010) and Dschaak et al. (2010) reported no effects on DMI when SS were supplemented up to $5 \%$ DM. Contrary to these findings, supplementing whole sunflower seed at a relatively high concentration (15.0\% DM) resulted in decreased DMI in lactating dairy cows (Mansoori et al., 2011), whereas an increase in DMI was observed by Beauchemin et al. (2009) when feeding crushed sunflower seed at $10.6 \%$ $\mathrm{DM}$. The intake of $\mathrm{OM}$ and $\mathrm{CP}$ were not affected by SS inclusion in this study. However, feeding the NSST decreased and tended $(P=0.06)$ to decrease intake of NDF and ADF compared with the CST and the CSST, respectively, due to lower NDF and ADF concentrations of NSS reported earlier. Substituting NSS for CS also decreased the intake of NDF and ADF (Dschaak et al., 2010). Mansoori et al. (2011) observed decreased intake of NDF when feeding whole sunflower seed at high (15.0\% DM) and low (7.5\% DM) levels.

Total tract digestibilities of DM, OM, CP, NDF, and ADF were not influenced by SS inclusion (Table 3 ). Total tract digestibilities of DM and OM increased when cows were fed NSS up to $3.0 \%$ DM compared with those fed the CS diet, but digestibilities of CP, NDF, and ADF did not differ (Dschaak et al., 2010). Similarly, total tract digestibilities of NDF and OM were not affected by feeding SS up to 5\% DM (Alizadeh et al., 2010), whereas feeding crushed sunflower seed at $10.6 \%$ DM dramatically decreased DM and OM digestibilities at 19.7 and $15.4 \%$, respectively (Beauchemin et

Table 3. Nutrient intake and total tract digestibility of lactating cows fed different safflower seeds

\begin{tabular}{|c|c|c|c|c|c|}
\hline \multirow[b]{2}{*}{ Item } & \multicolumn{3}{|c|}{ Dietary treatment ${ }^{1}$} & \multirow[b]{2}{*}{ SEM } & \multirow[b]{2}{*}{$P$-value } \\
\hline & CST & CSST & NSST & & \\
\hline \multicolumn{6}{|c|}{ Intake, $\mathrm{kg} / \mathrm{d}$} \\
\hline $\mathrm{DM}$ & 21.4 & 22.0 & 21.9 & 0.63 & 0.48 \\
\hline $\mathrm{OM}$ & 19.1 & 19.4 & 19.1 & 0.99 & 0.55 \\
\hline $\mathrm{CP}$ & 3.35 & 3.42 & 3.38 & 0.184 & 0.49 \\
\hline NDF & $8.42^{\mathrm{a}}$ & $8.28^{\mathrm{a}}$ & $7.77^{\mathrm{b}}$ & 0.481 & $<0.01$ \\
\hline $\mathrm{ADF}$ & 5.45 & 5.07 & 5.04 & 0.328 & 0.06 \\
\hline \multicolumn{6}{|c|}{ Digestibility, \% } \\
\hline $\mathrm{DM}$ & 70.1 & 71.2 & 72.4 & 1.62 & 0.58 \\
\hline $\mathrm{OM}$ & 72.6 & 73.7 & 74.8 & 1.65 & 0.58 \\
\hline $\mathrm{CP}$ & 68.9 & 70.3 & 71.3 & 1.65 & 0.52 \\
\hline $\mathrm{NDF}$ & 61.3 & 60.7 & 62.6 & 1.45 & 0.55 \\
\hline $\mathrm{ADF}$ & 58.5 & 57.8 & 61.3 & 2.63 & 0.56 \\
\hline
\end{tabular}

a,b Means within a row that do not have a common superscript differ at $P<0.05$.

${ }^{1} \mathrm{CST}=$ whole linted cottonseed TMR without whole safflower seed; CSST $=$ whole conventional safflower seed TMR; NSST = whole NutraSaff safflower seed (Safflower Technologies International, Sidney, MT) TMR. 
Table 4. Milk production and composition and efficiencies of DM and $\mathrm{N}$ use for milk production of lactating cows fed different safflower seeds

\begin{tabular}{|c|c|c|c|c|c|}
\hline \multirow[b]{2}{*}{ Item } & \multicolumn{3}{|c|}{ Dietary treatment ${ }^{1}$} & \multirow[b]{2}{*}{ SEM } & \multirow[b]{2}{*}{$P$-value } \\
\hline & CST & CSST & NSST & & \\
\hline Milk yield, $\mathrm{kg} / \mathrm{d}$ & 30.4 & 30.7 & 31.7 & 1.13 & 0.72 \\
\hline $3.5 \%$ FCM yield, $\mathrm{kg} / \mathrm{d}$ & 29.4 & 28.6 & 28.9 & 1.47 & 0.92 \\
\hline \multicolumn{6}{|l|}{ Milk composition, \% } \\
\hline Fat & 3.50 & 3.34 & 3.26 & 0.194 & 0.45 \\
\hline True protein & 3.01 & 3.03 & 3.05 & 0.071 & 0.94 \\
\hline Lactose & 4.62 & 4.66 & 4.65 & 0.058 & 0.88 \\
\hline MUN, mg/dL & 11.0 & 11.2 & 10.6 & 0.47 & 0.66 \\
\hline \multicolumn{6}{|c|}{ Milk component yield, $\mathrm{kg} / \mathrm{d}$} \\
\hline Fat & 1.05 & 1.00 & 1.01 & 0.078 & 0.81 \\
\hline True protein & 0.93 & 0.93 & 0.97 & 0.046 & 0.75 \\
\hline Lactose & 1.40 & 1.43 & 1.47 & 0.052 & 0.66 \\
\hline \multicolumn{6}{|l|}{ Efficiency } \\
\hline Milk/DMI & 1.41 & 1.39 & 1.45 & 0.057 & 0.69 \\
\hline $3.5 \% \mathrm{FCM} / \mathrm{DMI}$ & 1.37 & 1.29 & 1.32 & 0.055 & 0.41 \\
\hline Milk N/N intake ${ }^{2}$ & 0.294 & 0.286 & 0.300 & 0.0137 & 0.47 \\
\hline
\end{tabular}

${ }^{1} \mathrm{CST}=$ whole linted cottonseed TMR without whole safflower seed; CSST $=$ whole conventional safflower seed TMR; NSST $=$ whole NutraSaff safflower seed (Safflower Technologies International, Sidney, MT) TMR. ${ }^{2}$ Efficiency of use of feed $\mathrm{N}$ to milk $\mathrm{N}=[$ (milk true protein, $\left.\mathrm{kg} / \mathrm{d} \div 0.93) \div 6.38\right] \div \mathrm{N}$ intake, $\mathrm{kg} / \mathrm{d}$ (Dschaak et al., 2010).

al., 2009). Polyunsaturated FA exerted a toxic effect on cellulolytic bacteria (Nagaraja et al., 1997) and protozoa (Doreau and Ferlay, 1995). This effect is probably through an action on the cell membrane, particularly of gram-positive bacteria (Martin et al., 2008). However, the relatively small amounts of polyunsaturated FA in SS used in our study would not affect cellulolytic activities in the rumen, resulting in no effects of adding CSS or NSS on fiber digestion in the current study.

\section{Milk Production and Its Efficiency}

Addition of SS in the diets of lactating cows did not influence milk and FCM yield (Table 4). In reviewing the literature where SS or sunflower seed have been fed to lactating dairy cows, milk yield response has been variable: no effects (Beauchemin et al., 2009; Alizadeh et al., 2010; Dschaak et al., 2010) or negative effects (Mansoori et al., 2011). These various responses may have resulted from inclusion rate, physiological condition of experimental animals, and diet composition. Milk composition (fat, true protein, and lactose) and MUN concentration were not affected by inclusion of SS. In addition, milk component yields (fat, true protein, and lactose) did not differ due to SS inclusion. Addition of increasing amounts of NSS linearly decreased milk fat concentration and yield, but milk true protein and lactose did not differ with NSS inclusion up to $4 \%$ DM (Dschaak et al., 2010). Similarly, milk composition (fat, true protein, and lactose) was not affected by SS inclusion in early lactation diets (Alizadeh et al., 2010) or by crushed (Beauchemin et al., 2009) or whole sunflower seed (Mansoori et al., 2011). Low-forage diets with rich C18:2 n-6 FA typically induce milk fat depression (Piperova et al., 2000; Loor et al., 2005; Chilliard et al., 2007), whereas supplementing oilseeds in foragebased diets with lipids containing a high concentration of C18:2 n-6, like in our case, does not affect milk fat synthesis (Roy et al., 2006; Chilliard et al., 2007).

Feed efficiency (milk yield/DMI and $3.5 \%$ FCM yield/DMI) and $\mathrm{N}$ efficiency (milk $\mathrm{N}$ yield/ $\mathrm{N}$ intake) were similar among treatments (Table 4). Efficiency of use of feed $\mathrm{N}$ to milk $\mathrm{N}$ was improved in cows fed the $1 \%$ NSS diet, but it tended to decrease $(P=0.08)$ when NSS inclusion rate increased (Dschaak et al., 2010). Similarly, feed efficiency (3.5\% FCM yield/DMI) did not differ by adding crushed sunflower seed in lactating dairy cow diets (Beauchemin et al., 2009).

\section{Ruminal Fermentation Characteristics}

Substitution of CS with SS did not influence ruminal $\mathrm{pH}$ profiles (Table 5). Likewise, ruminal $\mathrm{pH}$ was not affected by SS inclusion in early lactation diets (Alizadeh et al., 2010) and crushed sunflower seed (Beauchemin et al., 2009). In our study, the mean $\mathrm{pH}$ was 6.2 across all diets, and minimum ruminal $\mathrm{pH}$ was maintained above 5.7 for all diets. Ruminal $\mathrm{pH}$ less than 5.8 hardly $(<2.1$ $\mathrm{h} / \mathrm{d}$ ) occurred, signifying that all treatments did not interfere with ruminal fermentation due to adequate supply of forage NDF and its particle size, which, in turn, would provide sufficient buffering capacity in the rumen.

The total concentration of VFA was not affected by the addition of SS in diets (Table 5). Likewise, molar proportions of major VFA (acetate, propionate, and 
Table 5. Ruminal fermentation characteristics of lactating cows fed different safflower seeds

\begin{tabular}{|c|c|c|c|c|c|}
\hline \multirow[b]{2}{*}{ Item } & \multicolumn{3}{|c|}{ Dietary treatment ${ }^{1}$} & \multirow[b]{2}{*}{ SEM } & \multirow[b]{2}{*}{$P$-value } \\
\hline & CST & CSST & NSST & & \\
\hline Minimum pH & 5.70 & 5.71 & 5.76 & 0.059 & 0.74 \\
\hline Maximum pH & 6.87 & 6.83 & 6.78 & 0.058 & 0.56 \\
\hline Mean $\mathrm{pH}$ & 6.23 & 6.21 & 6.26 & 0.068 & 0.90 \\
\hline \multicolumn{6}{|l|}{$\mathrm{pH}<5.8$} \\
\hline Daily episodes & 25.7 & 27.3 & 11.7 & 14.67 & 0.72 \\
\hline Duration, h/d & 2.12 & 1.24 & 0.18 & 1.068 & 0.48 \\
\hline Area, $\mathrm{pH} \times \min$ & 8.42 & 3.00 & 0.60 & 4.102 & 0.43 \\
\hline Total VFA, mM & 151.7 & 157.1 & 155.3 & 8.36 & 0.61 \\
\hline \multicolumn{6}{|c|}{ Individual VFA, mol/100 mol } \\
\hline Acetate $(\mathrm{A})$ & 57.0 & 56.2 & 56.1 & 1.68 & 0.85 \\
\hline Propionate (P) & 27.5 & 27.3 & 27.9 & 1.48 & 0.88 \\
\hline Butyrate & 10.3 & 10.9 & 10.7 & 0.57 & 0.53 \\
\hline Valerate & 3.17 & 3.36 & 3.08 & 0.573 & 0.74 \\
\hline Isobutyrate & $0.65^{\mathrm{b}}$ & $0.74^{\mathrm{a}}$ & $0.72^{\mathrm{a}}$ & 0.015 & 0.04 \\
\hline Isovalerate & 0.93 & 1.09 & 1.09 & 0.093 & 0.16 \\
\hline $\mathrm{A}: \mathrm{P}$ & 2.07 & 2.06 & 2.01 & 0.180 & 0.88 \\
\hline $\mathrm{NH}_{3^{-}} \mathrm{N}, \mathrm{mg} / 100 \mathrm{~mL}$ & 8.47 & 7.20 & 8.00 & 1.381 & 0.83 \\
\hline
\end{tabular}

butyrate) did not differ across dietary treatments, and the acetate-to-propionate ratio was similar between treatments. However, branched-chain VFA, isobutyrate increased with SS addition in the diets. Alizadeh et al. (2010) reported that molar proportions of VFA were not changed by SS inclusion in early lactation diets, and no effects of supplementing crushed sunflower seed on total VFA concentration occurred; however, the butyrate proportion decreased (Beauchemin et al., 2009). Because feed intake as well as ruminal fermentation characteristics were similar, it is apparent that ruminal fermentation would not interfere with properties associated with SS in the diets tested in this study. The concentration of $\mathrm{NH}_{3}-\mathrm{N}$ was not affected by the addition of SS in the diets. Similarly, the $\mathrm{NH}_{3}-\mathrm{N}$ concentration did not differ among treatments with the addition of SS (Alizadeh et al., 2010). Ruminal $\mathrm{NH}_{3}-\mathrm{N}$ concentration increased by crushed sunflower seed due possibly to decrease in $\mathrm{N}$ uptake by ruminal microbes (Beauchemin et al., 2009). In our previous study (Dschaak et al., 2010), we reported that MUN concentration decreased in cows supplemented with $1 \%$ NSS diet compared with those fed a CS diet, whereas increasing the NSS inclusion level up to $4 \% \mathrm{DM}$ tended $(P=0.08)$ to improve the efficiency of use of feed $\mathrm{N}$ to milk $\mathrm{N}$. We speculated that it was likely that the N solubility of NSS might be lower than that of CS, thereby influencing ruminal $\mathrm{NH}_{3}-\mathrm{N}$ concentration and, consequently, MUN concentration (Dschaak et al., 2010). However, the $\mathrm{NH}_{3} \mathrm{~N}$ concentration did not differ among treatments in this study. The discrepancy between the previous and current studies may have resulted from differences in diet composition; the CST diet contained $34.6 \%$ non-fibrous carbohydrate, whereas a control diet having CS in the previous study (Dschaak et al., 2010) had 25.3\% nonfibrous carbohydrate, suggesting that the CST diet may provide sufficient soluble carbohydrate to capture ammonia during ruminal fermentation.

\section{FA Profiles in Ruminal Fluid and Milk}

The proportion of C16:0 in ruminal fluid was decreased by the addition of SS in the diets, having a similar proportion between the CSST and the NSST (Table 6). Greater intake of dietary C16:0 (565, 499, and $480 \mathrm{~g} / \mathrm{d}$ for the CST, the CSST, and the NSST, respectively) contributed to the higher proportion of the C16:0 in ruminal content of cows fed the CST. Although the concentration of C18:0 in the diets was low, and concentrations of unsaturated C18 FA, such as $\mathrm{C} 18: 2$ cis-9, cis-12 and C18:3 cis-9, cis- 12 , cis-15 in the diets, were high (Table 2), C18:0 was the major longchain FA in ruminal fluid from all diets. Concentrations of C18:0 and C18:1 trans-11 were not affected by the addition of SS in the diets. However, concentrations of C18:1 cis-9 $(P=0.10)$ and $\mathrm{C} 18: 2 \mathrm{n}-6(P=0.09)$ tended to increase by cows fed SS diets compared with those fed the CST. Concentrations of C18:1 trans-11 and C18:1 cis-9 in ruminal fluid of dairy cows were not affected by feeding flaxseed, but the concentration of $\mathrm{C} 18: 3 \mathrm{cis}$ 9, cis-12, cis-15 increased (Côrtes et al., 2010). The process of ruminal $\mathrm{BH}$ decreases the ruminal outflow of polyunsaturated FA and contributes to accumulation of cis and trans isomers in ruminant products, includ- 
ing trans monoenes. Mosley et al. (2002) demonstrated that C18:1 cis-9 could be a precursor for several transFA isomers including C18:1 trans-11 FA. The extent to which $\mathrm{C} 18: 1$ trans-11 is hydrogenated to $\mathrm{C} 18: 0$ via group B microorganisms depends on conditions in the rumen (Jenkins and McGuire, 2006). Hence, the extent and type of the ruminal $\mathrm{BH}$ process will determine both the amounts and structures of FA leaving the rumen (Fievez et al., 2007). The increased proportions of $\mathrm{C} 18: 1$ cis-9 and C18:2 n-6 FA in ruminal content of cows fed the CSST and the NSST indicate that CSS and NSS were partially protected from microbial $\mathrm{BH}$, and these SS did not proceed to completion of ruminal BH. Feeding lipids in the form of seeds rather than oils has often been suggested to limit ruminal $\mathrm{BH}$, because seed hulls would restrict bacterial access to lipids. Jenkins and Bridges (2007) found that whole seeds provide some protection from ruminal $\mathrm{BH}$ and help lessen the severity of digestion problems by encapsulation of antimicrobial FA within the hard outer seed coat. The oil would be released at a slower rate in the rumen, or some of the oil may escape ruminal BH (Jenkins and Bridges, 2007). Therefore, feeding whole oilseeds represents a means by which favorable changes in milk FA profile can be obtained (Grummer, 1991).

Physiological conditions of ruminal BH of unsaturated FA have been reported to be sizably affected by some factors such as ruminal $\mathrm{pH}$, amount of added fat, number of double bonds in FA, and ruminal turnover rate (Kalscheur et al., 1997a; Beam et al., 2000; Jenkins and Adams, 2002). Because we did not detect any negative effects on ruminal fermentation, and added amounts of dietary fat were relatively small in this study, it is likely that feeding SS may not greatly interfere with the ruminal $\mathrm{BH}$, exerting its effects on proportions of only C18:1 cis-9 and C18:2 n-6 FA in ruminal content.

Adding SS in diets of dairy cows decreased the proportion of C16:0 FA in milk with the concentration in the NSST diet being the lowest (Table 7). The higher proportion of C16:0 in milk by feeding the CST was associated with higher C16:0 in the CST diet as well as ruminal fluid. Similarly, Dschaak et al. (2010) reported a linear decrease of C16:0 in milk with increasing levels of NSS up to $4 \%$ DM. Inclusion of sunflower oil at $5.2 \%$ DM (Roy et al., 2006) and flaxseed at 4.2 (Côrtes et al., 2010) or 6.5\% DM (Caroprese et al., 2010) decreased C16:0 FA in milk, whereas supplementing fish oil at 1.1\% DM (Caroprese et al., 2010) had no effect when compared with cows fed a control diet with no added fat supplement. Glasser et al. (2008) reported that C18:2 in lipid supplements (like in safflower and sunflower seeds) was more inhibitory than C18:3 (like in flaxseed) on the percentage of $\mathrm{C} 16: 0$ in milk, probably through the inhibition of de novo synthesis of C16:0.

The proportion of C18:0 FA in milk tended $(P=$ $0.06)$ to increase when cows were fed the NSST diet (Table 7). Dschaak et al. (2010) reported that cows supplemented with NSS at 1\% DM decreased C18:0 concentration in milk, but when supplemented at 3 or 4\% DM, no difference was observed when compared with CS supplementation. Addition of sunflower oil in a corn silage-based diet (Roy et al., 2006) or in diets of grazing dairy cows (Rego et al., 2009) increased the proportion of C18:0 in milk of dairy cows. In addition, the C18:0 FA concentration was higher in the milk of cows fed flaxseed than that of cows fed fish oil, which could be ascribed to a reduced $\mathrm{BH}$ of $\mathrm{C} 18: 1$ to $\mathrm{C} 18: 0$ in the rumen when cows were fed fish oil (Caroprese et al.,

Table 6. Fatty acid composition in the ruminal fluid of lactating cows fed different safflower seeds

\begin{tabular}{lccccc}
\hline & \multicolumn{3}{c}{ Dietary treatment $^{2}$} & & \\
\cline { 2 - 4 } Fatty acid $^{1}$ & CST & CSST & NSST & SEM & P-value \\
\hline C12:0 & 0.41 & 0.41 & 0.47 & 0.065 & 0.80 \\
C14:0 & 2.05 & 2.06 & 2.24 & 0.272 & 0.86 \\
iso-15:0 & 1.95 & 2.23 & 2.35 & 0.306 & 0.65 \\
anteiso-15:0 & 1.65 & 1.19 & 1.28 & 0.233 & 0.40 \\
C15:0 & 0.46 & 0.33 & 0.39 & 0.043 & 0.21 \\
iso-16:0 & 5.02 & 4.98 & 4.88 & 0.595 & 0.98 \\
C16:0 & $23.5^{\mathrm{a}}$ & $21.6^{\mathrm{b}}$ & $21.8^{\mathrm{b}}$ & 1.10 & 0.02 \\
C18:0 & 37.5 & 36.6 & 38.2 & 1.28 & 0.70 \\
C18:1 trans-11 & 7.77 & 9.17 & 7.09 & 1.599 & 0.66 \\
C18:1 cis-9 $_{\text {C18:2 n-6 }}$ & 9.70 & 11.1 & 10.8 & 0.464 & 0.10 \\
C18:3 n-3 & 5.63 & 6.01 & 6.69 & 0.283 & 0.09 \\
C22:6 n-3 & 1.10 & 0.92 & 0.99 & 0.067 & 0.25 \\
\hline
\end{tabular}

a,b Means within a row that do not have a common superscript differ at $P<0.05$.

${ }^{1}$ Fatty acid composition was expressed as $\mathrm{g} / 100 \mathrm{~g}$ of fatty acid methyl esters.

${ }^{2} \mathrm{CST}=$ whole linted cottonseed TMR without whole safflower seed; CSST $=$ whole conventional safflower seed TMR; NSST = whole NutraSaff safflower seed (Safflower Technologies International, Sidney, MT) TMR. 
Table 7. Fatty acid composition in the milk of lactating cows fed different safflower seeds

\begin{tabular}{|c|c|c|c|c|c|}
\hline \multirow[b]{2}{*}{ Fatty $\operatorname{acid}^{1}$} & \multicolumn{3}{|c|}{ Dietary treatment ${ }^{2}$} & \multirow[b]{2}{*}{ SEM } & \multirow[b]{2}{*}{$P$-value } \\
\hline & CST & CSST & NSST & & \\
\hline C16:0 & $37.3^{\mathrm{a}}$ & $34.7^{\mathrm{b}}$ & $32.1^{\mathrm{c}}$ & 1.02 & $<0.01$ \\
\hline C16:1 trans-9 & 0.37 & 0.38 & 0.39 & 0.023 & 0.59 \\
\hline C16:1 cis-9 & 1.86 & 1.82 & 1.74 & 0.156 & 0.72 \\
\hline C17:0 & 0.70 & 0.67 & 0.63 & 0.042 & 0.25 \\
\hline $\mathrm{C} 17: 1$ cis-10 & 0.28 & 0.28 & 0.26 & 0.024 & 0.54 \\
\hline C18:0 & 8.12 & 8.15 & 9.14 & 0.694 & 0.06 \\
\hline C18:1 cis-9 & $16.2^{\mathrm{c}}$ & $18.1^{\mathrm{b}}$ & $19.8^{\mathrm{a}}$ & 0.82 & $<0.01$ \\
\hline C18:1 trans-9 & 0.096 & 0.149 & 0.155 & 0.0195 & $<0.01$ \\
\hline C18:1 trans-10 & $0.21^{\mathrm{b}}$ & $0.27^{\mathrm{ab}}$ & $0.36^{\mathrm{a}}$ & 0.038 & 0.03 \\
\hline C18:1 cis-11 & $1.24^{\mathrm{b}}$ & $1.35^{\mathrm{ab}}$ & $1.43^{\mathrm{a}}$ & 0.073 & 0.02 \\
\hline C18:1 trans- 11 & $1.02^{\mathrm{b}}$ & $0.89^{\mathrm{b}}$ & $1.33^{\mathrm{a}}$ & 0.101 & $<0.01$ \\
\hline $\mathrm{C} 18: 1$ trans, total & $2.34^{\mathrm{b}}$ & $2.63^{\mathrm{b}}$ & $3.37^{\mathrm{a}}$ & 0.169 & $<0.01$ \\
\hline cis-9, trans-11 CLA & 0.33 & 0.34 & 0.45 & 0.044 & 0.07 \\
\hline trans-10, cis-12 CLA & 0.027 & 0.028 & 0.027 & 0.0017 & 0.81 \\
\hline C18:2 n-6 & 2.31 & 2.49 & 2.52 & 0.186 & 0.21 \\
\hline C18:3 n-3 & 0.45 & 0.49 & 0.45 & 0.043 & 0.37 \\
\hline C18:3 n-6 & 0.036 & 0.042 & 0.036 & 0.0042 & 0.49 \\
\hline C20:0 & 0.10 & 0.11 & 0.10 & 0.008 & 0.65 \\
\hline C20:1 & 0.080 & 0.097 & 0.088 & 0.0058 & 0.08 \\
\hline $\mathrm{C} 20: 2$ & 0.049 & 0.048 & 0.057 & 0.0043 & 0.24 \\
\hline MUFA & $23.5^{\mathrm{c}}$ & $25.9^{\mathrm{b}}$ & $28.5^{\mathrm{a}}$ & 0.87 & $<0.01$ \\
\hline PUFA & 3.62 & 3.89 & 3.92 & 0.231 & 0.20 \\
\hline SFA & $71.9^{\mathrm{a}}$ & $70.1^{\mathrm{a}}$ & $67.4^{\mathrm{b}}$ & 0.95 & $<0.01$ \\
\hline SCFA & 6.91 & 7.09 & 6.85 & 0.261 & 0.80 \\
\hline MCFA & $60.2^{\mathrm{a}}$ & $58.4^{\mathrm{b}}$ & $54.9^{\mathrm{c}}$ & 1.28 & $<0.01$ \\
\hline LCFA & $31.9^{\mathrm{c}}$ & $34.4^{\mathrm{b}}$ & $38.1^{\mathrm{a}}$ & 1.36 & $<0.01$ \\
\hline \multicolumn{6}{|c|}{ a ${ }^{\mathrm{a}}$ Means in the same row with different superscripts differ $(P<0.05)$. } \\
\hline \multicolumn{6}{|c|}{ 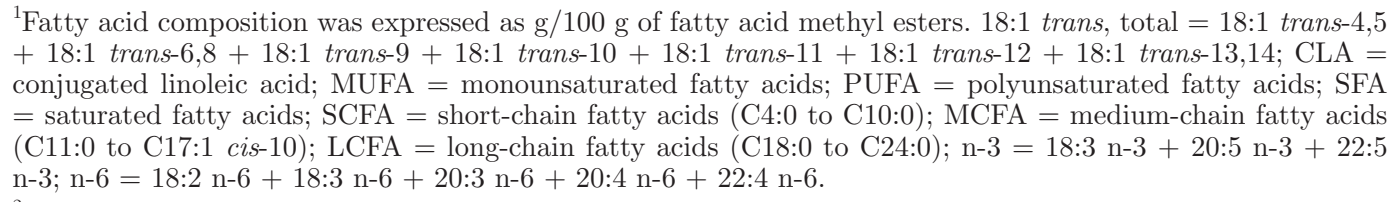 } \\
\hline \multicolumn{6}{|c|}{$\begin{array}{l}{ }^{2} \mathrm{CST}=\text { whole linted cottonseed TMR without whole safflower seed; CSST }=\text { whole conventional safflower } \\
\text { seed TMR; NSST }=\text { whole NutraSaff safflower seed (Safflower Technologies International, Sidney, MT) TMR. }\end{array}$} \\
\hline
\end{tabular}

2010). Supplementation with flaxseed tended $(P=0.07)$ to increase the proportion of C18:0 in milk compared with a control diet (Côrtes et al., 2010). Secretion of C18:0 in milk can be increased either by dietary C18:0 intake or by supplementation of C18 unsaturated FA, because they are in large part hydrogenated to C18:0 in the rumen (Chilliard et al., 2007). Lipid supplementation induces a general increase in C18:0 at the expense of the short- and medium-chain FA, resulting from an increase in mammary uptake of long-chain FA absorbed in the intestine and a decrease in mammary de novo FA synthesis (Palmquist et al., 1993; Glasser et al., 2008).

The concentration of C18:1 cis-9 in milk increased with SS addition in diets, with the NSST being the highest (Table 7). Dschaak et al. (2010) reported that addition of NSS showed a linear increase in the C18:1 cis-9 in milk with increasing amounts of NSS. Supplementation with flaxseed increased the proportion of C18:1 cis-9 in milk compared with a control diet (Caroprese et al., 2010; Côrtes et al., 2010); however, supplementation with fish oil did not affect C18:1 cis-9 in milk of dairy cows (Caroprese et al., 2010). Secretion of C18:1 cis-9 can be increased either through direct gut absorption and mammary secretion or mainly (ca. 80\%) from ruminal $\mathrm{BH}$, followed by mammary desaturation of C18:0 (Chilliard et al., 2007). In our case, the increased C18:1 cis-9 FA in milk of cows fed SS would be a direct effect of ruminal $\mathrm{BH}$, as it increased in rumen content. The concentration of C18:1 trans-10 increased with feeding the NSST, but not with the CSST compared with the CST. Although trans-10, cis-12 CLA has been identified as a potent inhibitor of milk fat synthesis (Bauman and Griinari, 2001), C18:1 trans-10 FA does not directly inhibit mammary synthesis of milk fat (Lock et al., 2007), although it responds to dietary factors, and its concentration is negatively correlated with milk fat yield response in cows (Bernard et al., 2008). In the current study, trans-10, cis-12 CLA did not differ among treatment diets, whereas C18:1 trans-10 FA was increased with feeding the NSST, but not with the 
CSST compared with the CST. The increase in the C18:1 trans-10 concentration of milk fat is indicative of complex changes in ruminal $\mathrm{BH}$ pathways, so the C18:1 trans-10 FA has been suggested as an alternative marker for the type of alterations in rumen $\mathrm{BH}$ that characterize diet-induced milk fat depression (Lock et al., 2007). As we did not find any effect of feeding the NSST on milk fat yield, the increased C18:1 trans-10 FA with feeding the NSST should not exert significant effects on de novo FA synthesis in the mammary gland.

The concentration of cis-9, trans-11 CLA in milk tended $(P=0.07)$ to increase when feeding the NSST compared with the CST and the CSST, whereas concentration of trans-10, cis-12-CLA was not affected by dietary treatments (Table 7 ). The increase in cis9, trans-11 CLA was linked to the increase in C18:1 trans-11 FA, a main precursor of cis-9, trans-11 CLA in milk. Dschaak et al. (2010) reported that supplementation of NSS linearly increased concentration of cis-9, trans-11 CLA with increasing NSS inclusion level. Despite its ruminal origin, the majority of cis- 9 , trans- 11 CLA in milk is synthesized within the mammary gland from C18:1 trans-11 via $\Delta^{9}$-desaturase (Loor and Herbein, 2003). In addition to the amount and type of oil, increasing evidence exists that milk FA composition responses to lipid supplements depend on the composition of the basal diet (Chilliard and Ferlay, 2004). For example, fat supplementation in high-forage diets such as the one used in our study typically result in a relatively low increase in the cis-9, trans-11 CLA concentration with a small increase in the C18:1 trans-11 isomer concentration (Chilliard et al., 2007). On the other hand, Kalscheur et al. (1997b) reported that BH of polyunsaturated FA in the rumen was reduced with high-concentrate diets, causing accumulation of C18:1 trans isomers and an increase in milk cis-9, trans-11 CLA.

It has been well established that the inclusion of unsaturated fat in dairy cow diets inhibits the de novo synthesis of short- and medium-chain FA and increases the concentration of C18 FA (Chilliard et al., 2007). In our study, the proportion of short-chain FA (4:0 to 10:0) in milk was not affected by dietary treatments, whereas medium-chain FA (11:0 to 17:0) decreased when CS was substituted with CSS, and further decreased by NSS. Rego et al. (2009) reported that short- and mediumchain FA decreased with sunflower oil supplementation, whereas Côrtes et al. (2010) reported that proportions of short-and medium-chain FA in milk fat were not affected by feeding flaxseed or fish oil. Long-chain FA $(\geq 18: 0)$ increased when CS was replaced with SS in the current study. Dschaak et al. (2010) reported a linear increase in long-chain FA with increasing levels of NSS in the diet. The concentrations of long-chain FA in milk fat were increased by the addition of flaxseed to the diet (Côrtes et al., 2010).

\section{CONCLUSIONS}

Supplementing SS on 3\% DM in lactation diets tested in this study did not have any negative effects on ruminal fermentation, lactational performance, and milk fat yield. Therefore, supplementing diets with whole SS at $3 \%$ of dietary DM can be an effective strategy of fat supplementation to lactating dairy cows without negative effects on lactational performance and milk FA profiles. Although milk FA C18:1 trans-11 and cis9, trans-11 CLA increased with feeding the NSST, but not with the CSST diet, no differences were observed in milk fat concentration as well as milk fat yield, suggesting that supplementing different whole SS in dairy diets would have limited effects on mammary FA synthesis.

\section{ACKNOWLEDGMENTS}

Funding for this project was provided by the Utah State University Extension Grant Program. The authors thank Safflower Technologies International (Sidney, MT) for generously supplying the NutraSaff safflower seed used in the study and for financially supporting the research. The authors are also grateful to S. J. McLeod (North Carolina State University, Raleigh, NC) for her technical assistance on ruminal FA analysis and the staff of the Caine Dairy Center, Utah State University (Wellsville, UT) for their conscientious care of the experimental cows. Additional support was provided by the Utah Agricultural Experiment Station (Utah State University, Logan).

\section{REFERENCES}

Alizadeh, A. R., G. R. Ghorbani, M. Alikhani, H. R. Rahmani, and A Nikkhah. 2010. Safflower seeds in corn silage and alfalfa hay based early lactation diets: A practice within an optimum forage choice. Anim. Feed Sci. Technol. 155:18-24.

Allen, M. S. 1997. Relationship between fermentation acid production in the rumen and the requirement for physically effective fiber. J. Dairy Sci. 80:1447-1462.

AOAC. 2000. Official Methods of Analysis. Vol. 1 and 2. 17th ed. AOAC Int., Gaithersburg, MD.

Bauman, D. E., and J. M. Griinari. 2001. Regulation and nutritional regulation of milk fat: Low-fat milk syndrome. Livest. Prod. Sci. 70:15-29.

Beam, T. M., T. C. Jenkins, P. J. Moate, R. A. Kohn, and D. L. Palmquist. 2000. Effects of amount and source of fat on the rates of lipolysis and biohydrogenation of fatty acids in ruminal contents. J. Dairy Sci. 83:2564-2573.

Beauchemin, K. A., S. M. McGinn, C. Benchaar, and L. Holtshausen 2009. Crushed sunflower, flax, or canola seeds in lactating dairy cow diets: Effects on methane production, rumen fermentation, and milk production. J. Dairy Sci. 92:2118-2127.

Beauchemin, K. A., and W. Z. Yang. 2005. Effects of physically effective fiber on intake, chewing activity, and ruminal acidosis for dairy cows fed diets based on corn silage. J. Dairy Sci. 88:2117-2129. 
Bergman, J. W., N. R. Riveland, C. R. Flynn, G. R. Carlson, D. M. Wichman, and K. D. Kephart. 2007. Registration of 'Nutrasaff' safflower. Journal of Plant Registrations 1:129-130.

Bernard, L., C. Leroux, and Y. Chilliard. 2008. Expression and nutritional regulation of lipogenic genes in the ruminant lactating mammary gland. Adv. Exp. Med. Biol. 606:67-108.

Bradley, V. L., R. L. Guenthner, R. C. Johnson, and R. M. Hannan. 1999. Evaluation of safflower germplasm for ornamental use. Pages 433-435 in Perspectives on New Crops and New Uses. J. Janick, ed. ASHS Press, Alexandria, VA.

Caroprese, M., A. Marzano, R. Marino, G. Gliatta, A. Muscio, and A. Sevi. 2010. Flaxseed supplementation improves fatty acid profile of cow milk. J. Dairy Sci. 93:2580-2588.

Chilliard, Y., and A. Ferlay. 2004. Dietary lipids and forages interactions on cow and goat milk fatty acid composition and sensory properties. Reprod. Nutr. Dev. 44:467-492.

Chilliard, Y., F. Glasser, A. Ferlay, L. Bernard, J. Rouel, and M. Doreau. 2007. Diet, rumen biohydrogenation and nutritional quality of cow and goat milk fat. Eur. J. Lipid Sci. Technol. 109:828855 .

Chouinard, P. Y., L. Corneau, D. M. Barbano, L. E. Metzger, and D. E. Bauman. 1999. Conjugated linoleic acid alters milk fatty acid composition and inhibits milk fat secretion in dairy cows. J. Nutr. 129:1579-1584.

Côrtes, C., D. C. da Silva-Kazama, R. Kazama, N. Gagnon, C. Benchaar, G. T. D. Santos, L. M. Zeoula, and H. V. Petit. 2010. Milk composition, milk fatty acid profile, digestion, and ruminal fermentation in dairy cows fed whole flaxseed and calcium salts of flaxseed oil. J. Dairy Sci. 93:3146-3157.

Doreau, M., and A. Ferlay. 1995. Effect of dietary lipids on nitrogen metabolism in the rumen: A review. Livest. Prod. Sci. 43:97-110.

Dschaak, C. M., J.-S. Eun, A. J. Young, and J. W. Bergman. 2010. Nutritive merits of whole Nutrasaff safflower seed when fed to Holstein dairy cows during midlactation. Anim. Feed Sci. Technol. $156: 26-36$.

Eun, J.-S., and K. A. Beauchemin. 2005. Effects of a proteolytic feed enzyme on intake, digestion, ruminal fermentation, and milk production. J. Dairy Sci. 88:2140-2153.

Fievez, V., B. Vlaeminck, T. C. Jenkins, F. Enjalbert, and M. Doreau. 2007. Assessing rumen biohydrogenation and its manipulation in vivo, in vitro and in situ. Eur. J. Lipid Sci. Technol. 109:740-756.

Glasser, F., A. Ferlay, and Y. Chilliard. 2008. Oilseed lipid supplements and fatty acid composition of cow milk: A meta-analysis. J. Dairy Sci. 91:4687-4703.

Grummer, R. R. 1991. Effect of feed on the composition of milk fat. J. Dairy Sci. 74:3244-3257.

Hurley, W. L., G. J. Warner, and R. R. Grummer. 1987. Changes in triglyceride fatty acid composition of mammary secretions during involution. J. Dairy Sci. 70:2406-2410.

Jenkins, T. C., and C. S. Adams. 2002. The biohydrogenation of linoleamide in vitro and its effects on linoleic acid concentration in duodenal contents and sheep. J. Anim. Sci. 80:533-540.

Jenkins, T. C., and W. C. Bridges Jr.. 2007. Protection of fatty acids against ruminal biohydrogenation in cattle. Eur. J. Lipid Sci. Technol. 109:778-789.

Jenkins, T. C., and M. A. McGuire. 2006. Major advances in nutrition: Impact on milk composition. J. Dairy Sci. 89:1302-1310.

Kalscheur, K. F., B. B. Teter, L. S. Piperova, and R. A. Erdman. 1997a. Effect of fat source on duodenal flow of trans-C18:1 fatty acids and milk fat production in dairy cows. J. Dairy Sci. $80: 2115-2126$

Kalscheur, K. F., B. B. Teter, L. S. Piperova, and R. A. Erdman. 1997b. Effect of dietary forage concentration and buffer addition on duodenal flow of trans-C18:1 fatty acids and milk fat production in dairy cows. J. Dairy Sci. 80:2104-2114.

Kleinschmit, D. H., D. J. Schingoethe, A. R. Hippen, and K. F. Kalscheur. 2007. Dried distillers grains plus solubles with corn silage or alfalfa hay as the primary forage source in dairy cow diets. J. Dairy Sci. 90:5587-5599.

Kononoff, P. J., and A. J. Heinrichs. 2007. Evaluating particle size of forages and TMRs using the New Penn State Forage Particle Sepa- rator. Penn State, College of Agricultural Sciences, Cooperative Extension, DAS 02-42. Pennsylvania State University, University Park.

Kononoff, P. J., A. J. Heinrichs, and D. A. Buckmaster. 2003. Modification of the Penn State forage and total mixed ration separator and the effects of moisture content on its measurements. J. Dairy Sci. 86:1858-1863.

Kramer, J. K. G., V. Fellner, M. R. Dugan, F. D. Sauer, M. M. Mossoba, and M. P. Yurawecz. 1997. Evaluating acid and base catalysts in the methylation of milk and rumen fatty acids with special emphasis on conjugated dienes and total trans fatty acids. Lipids $32: 1219-1228$

Li, D., and H.-H. Mündel. 1996. Safflower Carthamus tinctorius L. Promoting the conservation and use of underutilized and neglected crops. 7. Inst. Plant Genet. Crop Plant Res., Gatersleben/Int. Plant Genet. Resources Inst., Rome, Italy.

Littell, R. C., P. R. Henry, and C. B. Ammerman. 1998. Statistical analysis of repeated measures data using SAS procedures. J. Anim. Sci. 76:1216-1231.

Lock, A. L., C. Tyburczy, D. A. Dwyer, K. J. Harvatine, F. Destaillats, Z. Mouloungui, L. Candy, and D. E. Bauman. 2007. Trans-10 octadecenoic acid does not reduce milk fat synthesis in dairy cows. J. Nutr. 137:71-76.

Loor, J. J., A. Ferlay, A. Ollier, M. Doreau, and Y. Chilliard. 2005. Relationship among trans and conjugated fatty acids and bovine milk fat yield due to dietary concentrate and linseed oil. J. Dairy Sci. 88:726-740.

Loor, J. J., and J. H. Herbein. 2003. Reduced fatty acid synthesis and desaturation due to exogenous trans10, cis12-CLA in cows fed oleic or linoleic oil. J. Dairy Sci. 86:1354-1369.

Mansoori, H., A. Aghazadeh, and K. Nazeradl. 2011. Sunflower oil seed (raw-or heat-treated) in lactating dairy cow's diets: Effects on milk fatty acids profile and milk production. J. Anim. Vet. Adv. 10:470-479.

Martin, C., J. Rouel, J. P. Jouany, M. Doreau, and Y. Chilliard. 2008. Methane output and diet digestibility in response to feeding dairy cows crude linseed, extruded linseed, or linseed oil. J. Anim. Sci. 86:2642-2650.

Mosley, E. E., G. L. Powell, M. B. Riley, and T. C. Jenkins. 2002. Microbial biohydrogenation of oleic acid to trans isomers in vitro. J. Lipid Res. 43:290-296.

Nagaraja, T. G., C. J. Newbold, C. J. Van Nevel, and D. I. Demeyer. 1997. Manipulation of ruminal fermentation. Pages 523-632 in The Rumen Microbial Ecosystem. 2nd ed. P. N. Hobson and C. S. Stewart, ed. Blackie Academic \& Professional, New York, NY.

NRC. 2001. Nutrient Requirements of Dairy Cattle. National Academy Press, Washington, DC.

Overton, T. R., and M. R. Waldron. 2004. Nutritional management of transition dairy cows: Strategies to optimize metabolic health. J. Dairy Sci. 87:E105-E119.

Palmquist, D. L., A. D. Beaulieu, and D. M. Barbano. 1993. Feed and animal factors influencing milk fat composition. J. Dairy Sci. 76:1753-1771.

Penner, G. B., K. A. Beauchemin, and T. Mutsvangwa. 2006. An evaluation of the accuracy and precision of a stand-alone submersible continuous ruminal pH measurement system. J. Dairy Sci. $89: 2132-2140$

Piperova, L. S., B. B. Teter, I. Bruckental, J. Sampugna, S. E. Mills, M. P. Yurawecz, J. Fritsche, K. Ku, and R. A. Erdman. 2000. Mammary lipogenic enzyme activity, trans fatty acids and conjugated linoleic acids are altered in lactating dairy cows fed a milk fat-depressing diet. J. Nutr. 130:2568-2574.

Rego, O. A., S. P. Alves, L. M. S. Antunes, H. J. D. Rosa, C. F. M. Alfaia, J. A. M. Prates, A. R. J. Cabrita, A. J. M. Fonseca, and R. J. B. Bessa. 2009. Rumen biohydrogenation-derived fatty acids in milk fat from grazing dairy cows supplemented with rapeseed, sunflower, or linseed oils. J. Dairy Sci. 92:4530-4540.

Rhine, E. D., G. K. Sims, R. L. Mulvaney, and E. J. Pratt. 1998. Improving the Bertholot reaction for determining ammonium in soil extracts and water. Soil Sci. Soc. Am. J. 62:473-480. 
Roy, A., A. Ferlay, K. J. Shingfield, and Y. Chilliard. 2006. Examination of the persistency of milk fatty acid composition responses to plant oils in cows given different basal diets, with particular emphasis on trans-C18:1 fatty acids and isomers of conjugated linoleic acid. Anim. Sci. 82:479-492.

SAS Institute. 2001. SAS System for Microsoft Windows. Release 8.2 SAS Institute Inc., Cary, NC.

Sukhija, P. S., and D. L. Palmquist. 1988. Rapid method for determination of total fatty acid content and composition of feedstuffs and feces. J. Agric. Food Chem. 36:1202-1206.
Van Keulen, J., and B. A. Young. 1977. Evaluation of acid-insoluble ash as a natural marker in ruminant digestibility studies. J. Anim. Sci. 44:282-287.

Van Soest, P. J., J. B. Robertson, and B. A. Lewis. 1991. Methods of dietary fiber, neutral detergent fiber and non-starch polysaccharides in relation to animal nutrition. J. Dairy Sci. 74:3583-3597. 